\title{
KOMPROMISITAS ANTARA KREASI DAN PRODUKSI PRODUK BERBAHAN BAKU BONGGOL JAGUNG
}

\author{
Andry Masri ${ }^{1}$ \\ 1 Desain Produk, Fakultas Arsitektur dan Desain ITENAS. \\ Email: andry@itenas.ac.id
}

\begin{abstract}
Abstrak
Didasarkan pada hasil penelitian sebelumnya, diperoleh kesimpulan bahwa karakteristik bonggol jagung sebagai sebuah bahan baku alternatif dapat menghasilkan produk yang dapat menjadi komoditi yang memiliki peluang ekonomi yang baik. Hal ini sangat didukung oleh kenyataan bahwa bonggol jagung dapat dengan mudah diperoleh hampir diseluruh wilayah Indonesia, dan hingga saat ini belum dimanfaatkan secara ekonomi. Penelitian sebelumnya baru membuktikan bahwa bonggol jagung dapat dijadikan sebagai bahan baku yang mampu memberi nilai keunikan pada produk yang dihasilkan. Penelitian saat ini ditekankan pada aspek efesiensi produksi yang dikompromikan dengan aspek kreasi yang sebelumnya memberi penekanan pada keunikan produk, yang dijadikan sebuah nilai tawar bagi komoditi yang dihasilkan. Penekanan ini diberikan karena pada penelitian sebelumnya variabel kecepatan produksi, karakteristik mesin produksi yang sesuai belum digunakan. Dengan penekanan pada aspek produksi dan kesesuaian mesin produksi diharapkan kreasi berbahan baku bonggol jagung dapat menjadi salah satu komoditi industri yang realistis. Untuk dapat menjadi komoditi industri, diperlukan bentuk produk (kreasi) yang layak industri, efesien dan efektif dari sisi produksi sejalan dengan tetap memiliki kualitas visual yang mendukung terhadap nilai pemasaran.

Penelitian akan diawali oleh evaluasi terhadap desain produk berbahan baku bonggol jagung yang pernah dihasilkan. Evaluasi ditekankan pada efesiensi yang dapat dihasilkan oleh mesin yang saat ini digunakan. Hasil evaluasi akan menghasilkan kriteria terhadap kemampuan mesin yang seharusnya tepat digunakan. Paralel terhadap perancangan mesin produksi tersebut, akan dirancang beberapa desain yang tetap memiliki nilai visual yang baik akan tetapi memiliki kesesuaian dengan produk yang dirancang. Melalui metoda beberapa kali iterasi terhadap eksperimentasi akan diperoleh kriteria bentuk yang layak industri dan mesin produksi yang sesuai dengan karakteristik bahan baku konvensional tersebut. Hal ini sangat diperlukan karena bonggol jagung memiliki karakteristik material sendiri yang berbeda sehingga menuntut adanya kesesuaian dari mesinmesin produksi yang saat ini ada secara konvensional. Hasil penelitian menawarkan sekitar 24 produk prototype kreasi berbahan baku bonggol jagung yang teruji yang dihasilkan oleh mesin produksi yang layak secara industri dan pasar sebagai tawaran baru bagi dunia usaha di Indonesia.
\end{abstract}

Kata kunci: Produk Bonggol Jagung, Craft, Industri Craft.

\begin{abstract}
Based on the results of previous research, it is concluded that the characteristics of corncob as an alternative raw material can produce a product that can be a commodity that has good economic opportunities. This is strongly supported by the fact that corn cobs can be easily obtained in almost all parts of Indonesia, and until now it has not been used economically. Previous research has just proven that corncob can be used as a raw material that can give a unique value to the product being produced. Current research focuses on aspects of production efficiency that are compromised with aspects of creation that previously emphasized product uniqueness, which is used as a bargaining value for the commodities produced. This emphasis is given because in previous studies the variable speed of production, the characteristics of the appropriate production machines have not been used. With an emphasis on the aspects of production and the suitability of production machines, it is hoped that creations made from corncob as raw material can become a realistic industrial commodity. In
\end{abstract}

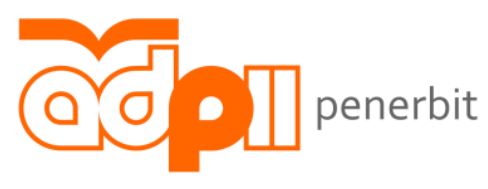

Penerbit Aliansi Desainer Produk Industri Indonesia 
order to become an industrial commodity, it requires a product form (creation) that is industrially appropriate, efficient and effective in terms of production, while maintaining a visual quality that supports marketing value.

The research will be initiated by an evaluation of the product designs made from corncob that have been produced. The evaluation emphasizes the efficiency that can be produced by the machines currently used. The results of the evaluation will produce criteria for machine capabilities that should be properly used. Parallel to the design of the production machine, several designs will be designed that still have good visual value but are in conformity with the product being designed. Through the method of several iterations of experimentation, the criteria for an appropriate industrial form and production machine will be obtained in accordance with the characteristics of these conventional raw materials. This is very necessary because the corncob has its own different material characteristics so that it demands conformity from conventional production machines. The results of the research offered around 24 prototype creations made from corncob that were tested and produced by industrial and market-worthy production machines as a new offer for the business world in Indonesia.

\section{Keywords: Corncob Product, Craft, Craft Industry}

\section{Pendahuluan}

Bahan baku bonggol jagung dapat diperoleh dengan mudah diseluruh daerah di Indonesia, dan hingga saat ini belum banyak dimanfaatkan sebagai bahan baku. Hal ini menjadikan industri yang diusulkan memiliki potensi yang sangat besar untuk dibangun di Indonesia yaitu sebuah industri skala kecil menengah sebagai alternatif industri baru bagi masyarakat umum dengan menekankan aspek kreatif sebagai salah satu kapital yang signifikan. Agar bonggol jagung dapat dijadikan sebagai bahan baku yang tepat, maka variabel besarnya ketersediaan bahan baku harus dilengkapi juga dengan variabel produksi yang tepat, yang memberi penekanan pada nilai efesiensi dan efektifitas.

Bonggol jagung sebagai bahan baku memiliki karaktersitik yang cukup signifikan berbeda dengan bahan baku konvensional seperti kayu, bambu, atau rotan. Perbedaan ini menyebabkan karakteristik mesin produksi yang juga berbeda, agar diperoleh nilai efektifitas serta efesiensi sebagai tuntutan industri. Sebagai industri dengan skala kecil menengah, menghadapi karakterstik bahan baku yang baru tersebut dituntut keterampilan tertentu yang bersifat baru juga bagi masyarakat. Disisi lain, masyarakat tidak memiliki dasar untuk mengolah bahan baku yang bersifat non konvensional seperti bonggol jagung. Oleh karenanya penelitian yang diajukan bertujuan untuk mendapatkan satu model bentuk industri yang tepat untuk menjawab korelasi antara karakteristik bahan baku, keterbatasan alat yang konvensional, dan harga sebagai nilai kerelaan, yang membutuhkan nilai kompromi diantara ketiganya.

Sebagai bentuk usaha, bentuk kompromi yang diharapkan adalah dapat ditentukannya jenis komoditi yang tepat dari craft berbahan baku bonggol jagung tersebut yang mampu memberi nilai komersil sekaligus estetik. Bentuk kompromi ini selanjutnya akan mempengaruhi karakteristik produksi yang harus diterapkan agar nilai estetik akan sejalan dengan nilai komersil yang diharapkan. Hasil penelitian akan menawarkan sebuah prototype kreasi berbahan baku bonggol jagung yang teruji sebagai tawaran baru bagi dunia usaha di Indonesia. Sesuai dengan skema yang dipilih, penelitian ini ditujukan untuk mendapatkan solusi baru bagi permasalahan masyarakat untuk memperoleh bentuk usaha yang dapat dijalankan dalam menghadapi persaingan pasar, khususnya pada bidang craft, yang didukung oleh sumber daya alam yang ada disekitar lingkungan masyarakat itu sendiri. Penelitian yang diusulkan berada pada TKT tingkat 5 dengan bidang fokus pada sosial humaniora-seni budaya.

Inovasi dianggap sebagai komponen dasar kewirausahaan. Hal ini diyakini karena inovasi dianggap sebagai sarana untuk menciptakan dan mempertahankan keunggulan kompetitif yang berkelanjutan, dan dianggap sebagai kunci sukses sebuah bisnis [1]. Inovasi adalah hasil dari proses kreatif, sementara kreatifitas sendiri sebagai dapat dipahami sebagai pemikiran yang memungkinkan seseorang untuk menerapkan imajinasi mereka dalam menghasilkan ide, pertanyaan dan hipotesis, bereksperimen dengan alternatif dan untuk mengevaluasi ide mereka sendiri dan orang lain, produk dan proses akhir [2]. Terkait dengan inovasi, kebaruan adalah konsep yang seolah kompleks dan berlapis, melibatkan banyak ragam elemen yang berbeda, yang

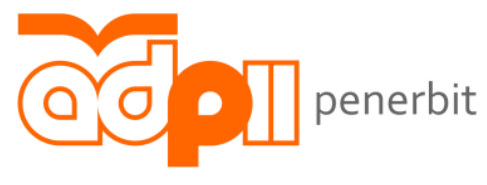

Penerbit Aliansi Desainer Produk Industri Indonesia 
berkontribusi terhadap pengertian dan pengalaman inovasi, multiplisitas, refleksivitas dan interaktifitas [3]. Istilah kebaruan berkaitan erat dengan terminologi kreatifitas dan inovasi. Kreatifitas adalah potensi manusia, yang ada pada pikiran manusia, sedangkan inovasi merupakan implementasi dari pemikiran kreatif untuk diwujudkan. Dengan kata lain, dapat dikatakan kreatifitas adalah pemikiran yang ada dalam proses seseorang untuk melakukan inovasi, dan kebaruan adalah nilai dari wujud inovasi itu sendiri. Kebaruan sendiri sebagai hasil dari inovasi dari sebuah produk sangat jarang dipandang dari perspektif desain [4].

Sementara itu, kebaruan sendiri adalah hal yang seharusnya mudah untuk ditemukan pada bidang craft. Khusus pada pendekatan ekplorasi material sebagai salah satu pendekatan pada bidang craft di akademik, telah diujikan penggunaannya pada masyarakat, dan terbukti bahwa pendekatan tersebut dapat dilakukan dengan mudah oleh masyarakat sebagai salah satu pendekatan yang menitik beratkan menghasilkan kebaruan melalui pemahaman material [5]. Masuknya craft pada salah satu subsektor ekonomi kreatif menunjukkan bahwa bidang ini sesungguhnya memperlihatkan bahwa kreatifitas adalah modal dari industri tersebut. Permasalahan yang muncul adalah bagaimana sesungguhnya kreatifitas tersebut dapat diimplementasikan pada industri yang sesungguhnya.

\section{Metodologi}

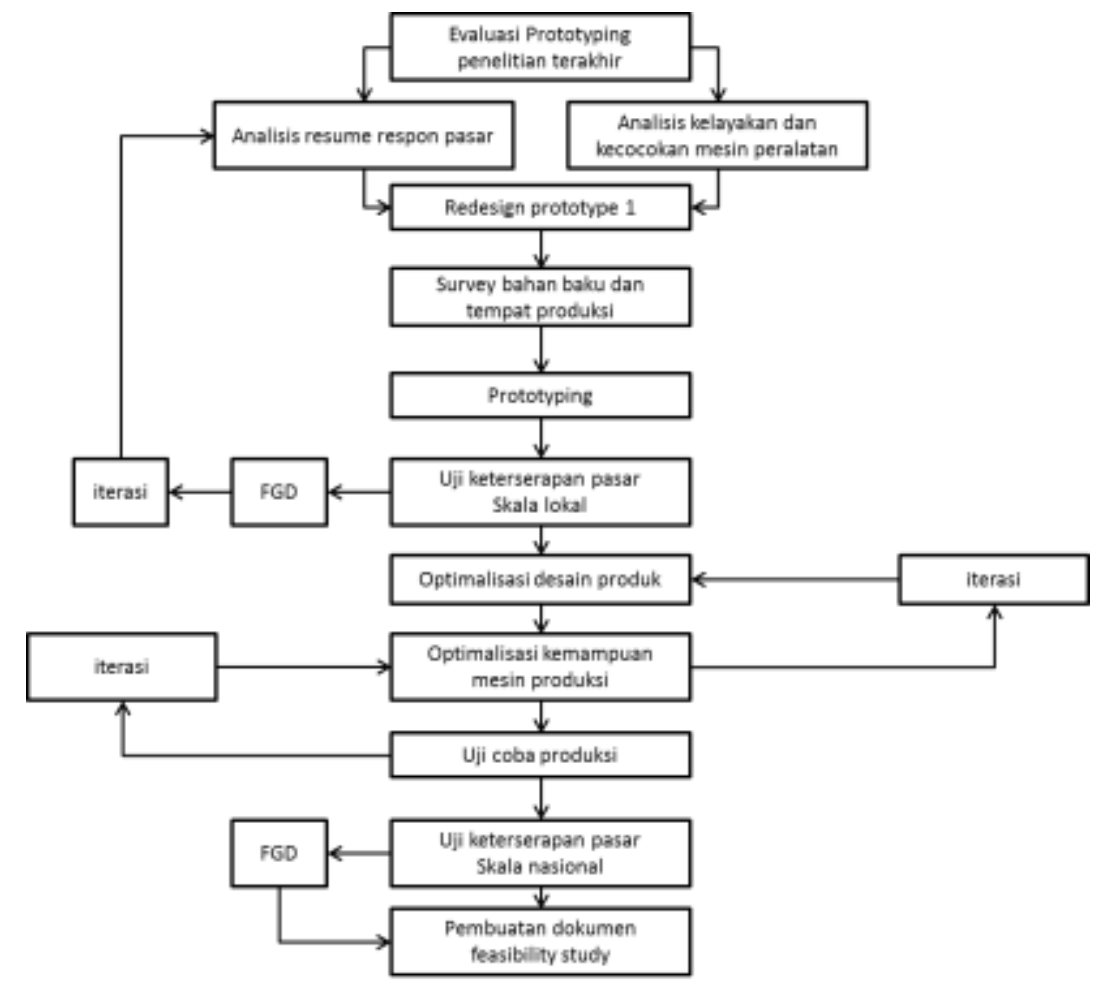

Gambar 1. Bagan proses penelitian

Penelitian akan diawali dari evaluasi terhadap prototype yang pernah dihasilkan melalui penelitian sebelumnya, dengan penekanan pada respon konsumen dan efesiensi produksi dari prototype yang dihasilkan.

Analisis respon diarahkan pada kecenderungan minat masyarakat pada nilai estetik yang ditawarkan oleh kreasi yang dihasilkan. Analisis kelayakan dan kecocokan mesin peralatan ditekankan kepada kesesuan desain dengan kemampuan mesin dan peralatan yang selama ini digunakan.

Dari hasil analisis tersebut, dilakukan proses redesign dengan penekanan pada aspek selera konsumen dan kemampuan mesin. Melengkapi proses tersebut, dilakukan juga analisis terhadap ketersediaan bahan baku dan kemungkinan tempat produksi yang tepat bagi industri yang akan direncanakan.

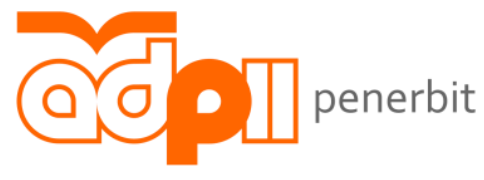

Penerbit Aliansi Desainer Produk Industri Indonesia 
Berdasarkan hal tersebut diatas, dibuatlah prototype untuk selanjutnya diuji cobakan pada pasar yang telah dituju pada skala lokal.

Hasil uji coba keterserapan pasar akan dirumuskan melalui FGD dengan tenaga ahli yang terkait dengan

bidang industri kreatif pada bidang craft, dan melalui beberapa iterasi akan dilakukan hingga diperoleh desain produk craft yang optimal.

Optimalisasi desain ini akan diselaraskan dengan optimalisasi mesin produksi yang akan disesuaikan berdasarkan karakteristik industri mitra, dan melalui proses beberapa iterasi akan dihasilkan pemanfaatan mesin produksi yang optimal. Hal ini akan mengarahkan pada uji coba produksi dengan kapasitas maksimal.

Hasil penyelarasan antara nilai estetik (desain) dan kemampuan mesin akan disesuaikan dengan kapasitas maksimal produksi. Hasil uji coba produksi ini akan diujikan keterserapan pasarnya pada skala nasional.

Melalui FGD dengan beberapa tenaga ahli terkait, akan dirumuskan feasibility study industri kreatif bidang craft yang tepat bagi masyarakat..

\section{Diskusi}

Penelitian ini bertujuan untuk mendapatkan satu model bentuk industri yang tepat dengan menjawab korelasi antara karakteristik bahan baku, keterbatasan alat yang konvensional, dan harga sebagai nilai kerelaan, yang membutuhkan nilai kompromi diantara ketiganya. Penelitian diawali dengan melakukan kajian terhadap peralatan yang tepat untuk digunakan, hal ini dilakukan dengan mengingat bahwa bahan baku yang digunakan adalah bahan baku yang tidak bersifat konvensional, yaitu bonggol jagung. Kajian terhadap alat yang tepat dilakukan agar diperoleh nilai efektifitas dan efesiensi, serta durabilitasnya sebagai sebuah industri. Kajian ini akan berjalan secara paralel dengan tuntutan bahwa kreasi yang dihasilkan harus dapat diterima dan diminati oleh masyarakat, sementara sebagai sebuah produk inovasi, produk berbahan baku bonggol jagung belum dikenal oleh masyarakat secara luas. Untuk mendapatkan model dari bentuk industri ini, maka fokus penelitian selanjutnya adalah mendapatkan jenis komoditi yang tepat, yang dapat difasilitasi oleh alat yang tepat dan memiliki kriteria durabilitas yang tinggi (tahun pertama).

Pada tahun kedua, tahap penelitian selanjutnya adalah mengkaji beragam kemungkinan jenis komoditi yang dapat dihasilkan oleh industri, dan kemudian mendapatkan harga produksi dari setiap desain yang dikaji. Dari hasil penetapan komoditi dan harga yang diperoleh, maka cashflow industri dapat direncanakan dengan baik. Tahap terakhir dari penelitian ini adalah inisiasi pengkajian terhadap keterserapan dari konsumen terhadap semua hasil desain produk berbahan baku bonggol jagung. Uji keterserapan konsumen tidak dapat dilakukan sehubungan dengan berlangsungnya pandemi covid di Indonesia, setidaknya 3 buah pameran berskala nasional yang sedianya akan diikuti, batal untuk dilaksanakan. Untuk mengganti hal tersebut, pada penelitian ini tetap dilakukan uji keterserapan pasar melalui media digital, walaupun tidak dapat diperoleh hasil yang sesuai dengan harapan.Kesimpulan.

Berisi mengenai ketercapaian dari tujuan penelitian dan uraian mengenai ketercapaian tujuan dari penelitian serta uraian khusus mengenai temuan yang dihasilkan melalui penelitian. 


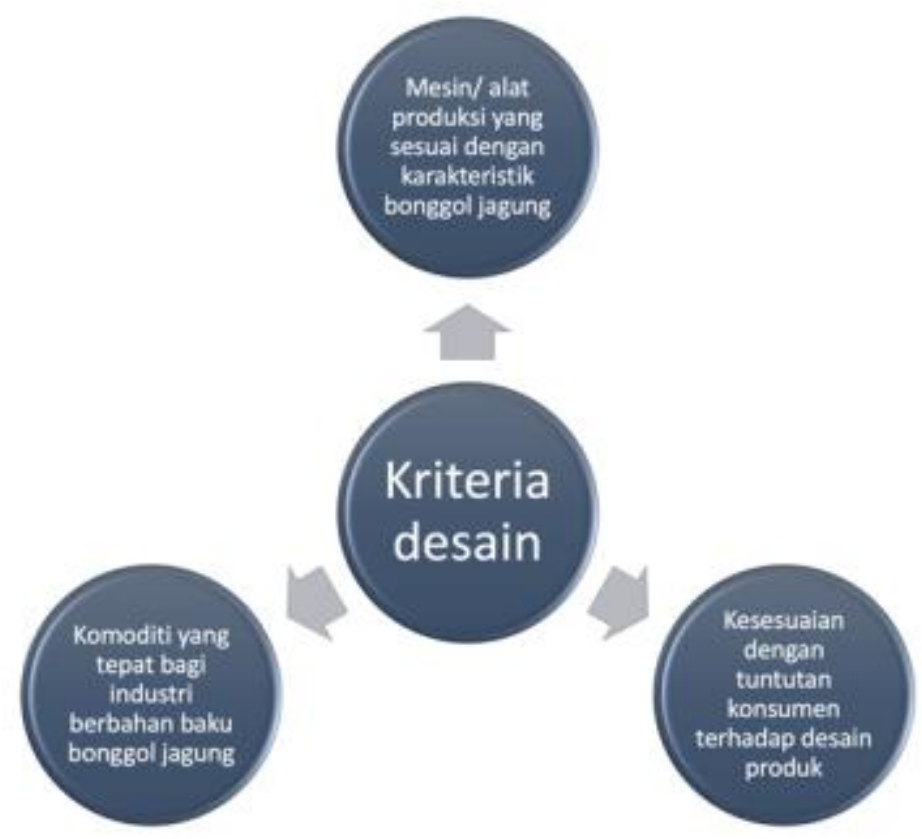

Gambar 2. bagan keterkaitan kompromi

Upaya untuk mendapatkan nilai kompromi ini merupakan langkah yang strategis agar produk inovasi ini dapat masuk kedalam tahap komersialisasi. Penekanan pada aspek desain ditujukan agar produk dapat diterima oleh masyarakat dengan pertimbangan kesesuaian dari faktor emosional konsumen pada orientasi pasar tertentu, dan penekanan pada aspek produksi akan menentukan harga produk yang selanjutnya akan menjadi pertimbangan terhadap kesesuaian dari kerelaan konsumen dalam membeli produk. Tercapainya nilai kompromi ini akan menjadi dasar yang kuat bahwa bonggol jagung sebagai bahan baku dari produk industri kreatif pada sektor craft dapat menjadi salah satu bukti dari keunggulan industri kreatif sebagai bagian dari ekonomi kreatif. Penelitian yang dilakukan oleh Widiya DA dan Agus PS menunjukkan bahwa orientasi pasar, inovasi dan kreatifitas produk berpengaruh positif dan signifikan terhadap kinerja industri kreatif untuk mencapai keunggulan bersaing [6]. Desain memiliki kontribusi pada hasil inovasi model bisnis, terdapat lima tema acuan dalam desain, yaitu : desain fungsional, desain berbasis hasil, desain sebagai metodologi, orientasi desain-logika, dan non-desain. Dari tema ini, empat karakteristiknya diidentifikasi sebagai mekanisme yang memungkinkan kontribusi desain untuk hasil Inovasi Model Bisnis yaitu desain fungsional, desain berbasis hasil, desain sebagai metodologi, dan orientasi desain-logika. Dari mekanisme ini, hanya desain fungsional yang ditemukan mencerminkan praktik desain industri klasik dengan fokus pada pengembangan produk, sementara tiga mekanisme desain lainnya yang berkontribusi pada Inovasi Model Bisnis sangat menarik dari pendekatan desain dan pemikiran desain yang berpusat pada pengguna baru-baru ini ke peran desain[7].

Persoalan dalam menentukan harga ini akan sangat mempengaruhi upaya komersialisasi dari produk yang dihasilkan. Produk bonggol jagung adalah produk yang benar-benar baru, oleh karena itu upaya komersialisasi akan menuntut usaha yang sangat besar, karena sebagian besar konsumen memiliki keengganan yang tinggi untuk mengadopsi sebuah produk yang benar benar baru, Konsumen memiliki sikap dualistik terhadap inovasi produk. Konsumen diketahui memiliki kecenderungan inheren untuk mendekati (neofilia) dan menghindari (neofobia) produk baru pada saat yang bersamaan [8]. Pada studi yang terakhir, ditunjukkan bahwa terdapat isyarat yang meredam kekhasan (yaitu, isyarat popularitas) dan isyarat yang meningkatkan kekhasan (yaitu, isyarat kelangkaan), yang selanjutnya dapat membalikkan efek perspektif diri sehingga diri yang mandiri menjadi kurang bersedia untuk mengadopsi produk yang benar-benar baru dan lebih bersedia untuk mengadopsi produk baru secara bertahap [9]. Pada keikut sertaan sebuah pameran yang diselenggarakan oleh L2Dikti wilayah 4, diperoleh fakta bahwa masyarakat tidak segera dapat mengadopsi produk berbahan baku bonggol jagung, terdapat faktor yang menghambat konsumen untuk menerima kehadiran produk berbahan

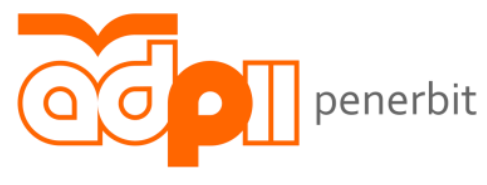

Penerbit Aliansi Desainer Produk Industri Indonesia 
baku bonggol jagung tersebut, hal ini mengindikasikan bahwa diperlukan upaya yang sangat besar untuk memberikan edukasi pada masyarakat mengenai produk baru berbahan baku bonggol jagung. Salah satu komponen dalam keterserapan produk pada masyarakat adalah kualitas visual dari produk itu sendiri. Penampilan visual produk memainkan peran penting dalam menentukan respons konsumen, tampilan dari produk mungkin menyediakan persyaratan konsumen yang tidak diartikulasikan dan menyarankan kualitas produk yang sulit untuk dipastikan. Pertimbangan tentang apakah suatu produk menarik tidak hanya mencakup pertimbangan apakah produk tersebut terlihat bagus, tetapi juga apakah produk tersebut tampak berfungsi dan mengatakan hal yang benar terkait dengan pemiliknya. Dengan demikian, penampilan produk mempengaruhi kesuksesan komersial dan kualitas hidup konsumen [10]. 'Realitas' dari desain produk adalah bahwa baik bentuk produk maupun tanggapan konsumen ditentukan oleh berbagai faktor dan faktor-faktor ini berinteraksi satu sama lain dalam cara yang kompleks dan tidak dapat diprediksi [11].

Melalui penelitian yang dilakukan selama 2 tahun ini, diperoleh harga jual produk yang dicapai melalui nilai kompromis antara faktor kreasi dan faktor produksi. Pada penelitian tersebut, dilakukan proses pengkajian terhadap beragam kemungkinan desain dari beberapa jenis komoditi, seperti furniture dan merchandise. Harga yang diperoleh akan sangat mempengaruhi penilaian terhadap tepat tidaknya komoditas yang dipilih dengan kesesuaian harga berdasarkan perbandingan harga antara produk berbahan baku bonggol jagung dengan produk sejenis dari bahan baku lain.

Sebagai contoh, desain pertama yang dihasilkan untuk mendapatkan harga jual adalah stool kotak yang harus dibandingkan dengan produk sejenis lainnya dari bahan baku yang konvensional.

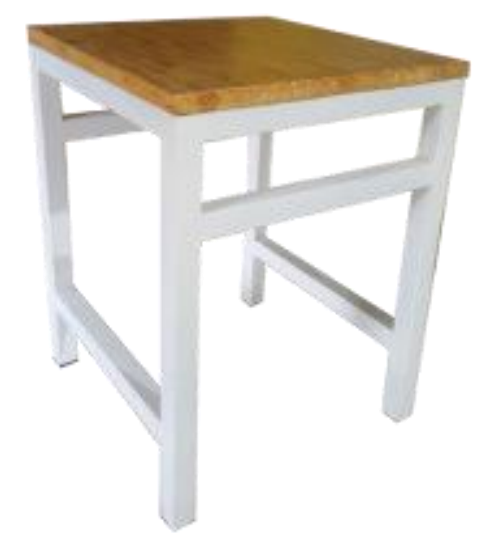

\section{Gambar 3. Stool kotak Bonggol jagung}

Pada stool kotak diatas, permasalahan utama yang muncul saat eksperimen dilakukan adalah kepercayaan seseorang untuk duduk pada stool ini. Alternatif solusi yang diusulkan adalah menambah papan dengan merekatkan papan kedua menyilang, akan tetapi hal ini akan menyebabkan harga produksi yang meningkat 2 kali lipat, sehingga untuk mendapatkan kekuatannya, konstruksi alas duduk diberi besi melintang pada pertengahan kotak.

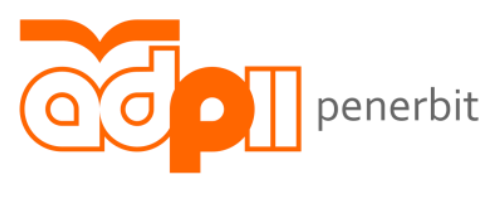

Penerbit Aliansi Desainer Produk Industri Indonesia 


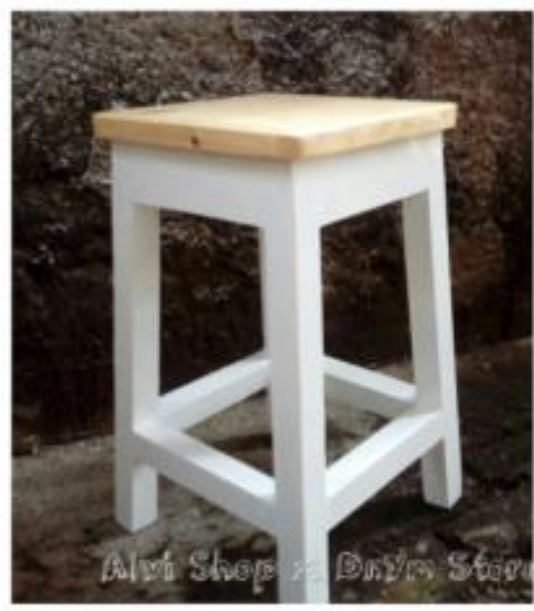

Rp. 120.000

Jurnal Desain Indonesia Vol. 02 no. 02 - Aliansi Desainer Produk Industri Indonesia

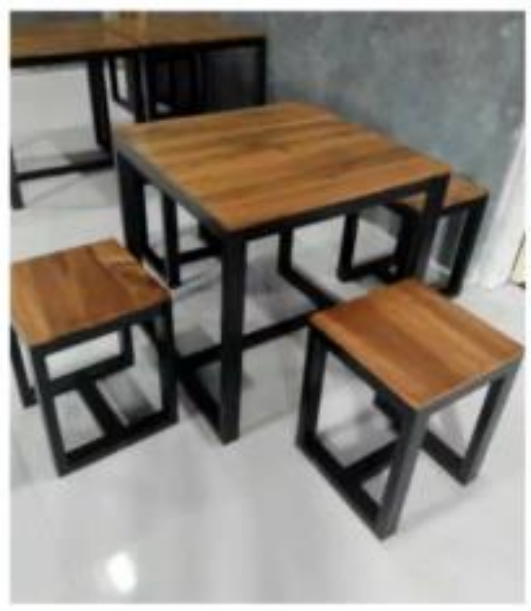

Rp. 155.000

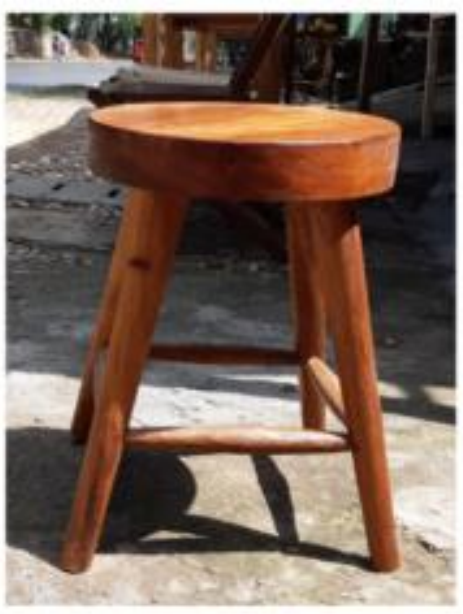

Rp. 200.000

\section{Gambar 4. Perbandingan dengan produk berbahan baku lain}

Tidak diperoleh keunggulan produk dari stool yang ditawarkan, mengingat harga stool yang ada di pasaran masih berada pada harga dibawah harga produksi dari stool yang dirancang. Disamping bahwa secara visual, stool sangat bersifat geometris, sebagian besar responden masih menilai harga produk yang ditawarkan terlalu tinggi. Dengan keuntungan sebesar $15 \%$, stool hanya dapat ditekan pada harga jual sekitar Rp. 400.000. Hingga saat ini belum dapat ditemukan solusi terhadap permasalahan ini, alternatif untuk mendapatkan kualitas visual adalah dengan pemilihan penggunaan bahan pendukung seperti kayu atau bambu, akan tetapi hal ini menyebabkan harga jual yang meningkat lagi. Pemilihan jenis besi hollow belum dapat digantikan oleh material lain, sehingga produk ini agak sulit untuk dikembangkan lebih lanjut. Kemampuan produksi dengan menggunakan 1 mesin, dan 2 orang pekerja adalah 5 buah produk dengan waktu pengerjaan 4 hari. Proses perbandingan dan eksperimen ini dilakukan dengan pola yang sama terhadap setidaknya 23 komoditi yang lain, dan ditemukan beberapa permasalahan yang bergantung pada jenis komoditi.

Penelitian ini menghasilkan setidaknya 24 komoditi desain yang telah mendapatkan nilai kelayakan produksi sehingga nilai harga produksi dapat ditentukan, yang selanjutnya dapat dibuka peluang untuk mendapatkan nilai harga jual dari setiap komoditi yang dihasilkan. Dari 24 komoditi desain tersebut, telah didaftarkan HKI dari Desain Industri sebanyak 6 buah desain, proses ini telah berjalan lebih dari setahun, akan tetapi dokumen haki belum juga diterbitkan. Sementara itu, didaftarkan pula 11 Hak Cipta, akan tetapi terhambat oleh penolakan yang sedang dikonfirmasikan kembali terkait dengan pasal 43 c undang-undang Hak Cipta no. 28 tahun 2014 terkait klausul tujuan fungsional.

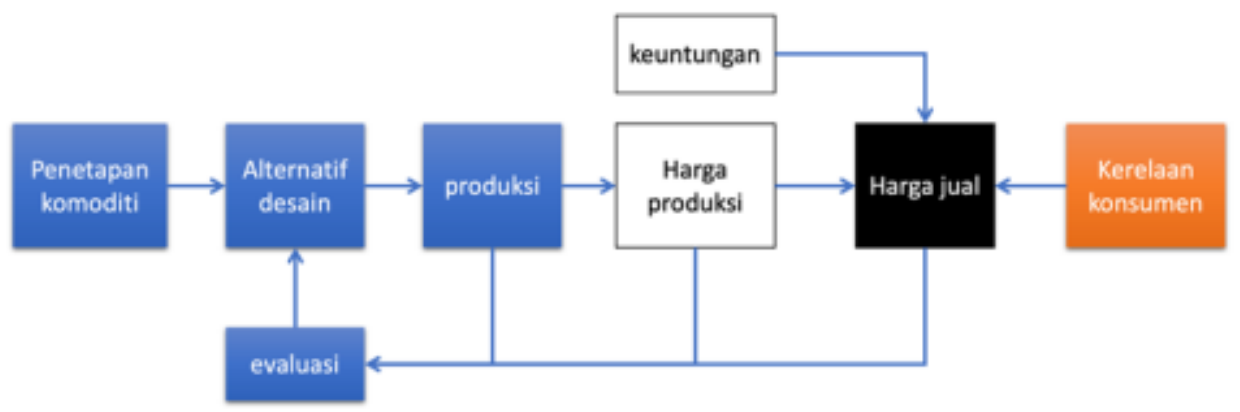

Gambar 5. aspek yang harus dikompromikan pada penelitian

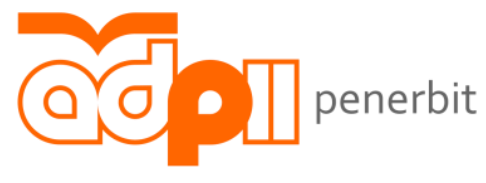

Penerbit Aliansi Desainer Produk Industri Indonesia 
Seperti yang digambarkan pada bagan 2 diatas, penelitian dilakukan melalui metoda iterasi antara nilai desain dan produksi dalam bentuk eksperimen secara langsung. Pendekatan ini dilakukan mengingat bahwa bahan baku yang digunakan bersifat sangat baru, sehingga acuan efesiensi produksi tidak dapat ditetapkan sejak awal. Metoda ini diawali dengan penetapan komoditas yang akan dirancang dengan mempertimbangkan efesiensi produksi dengan krieria yang telah ditetapkan pada tahun pertama. Berdasarkan hal tersebut ditetapkan jumlah yang dimungkinkan sesuai dengan hari kerja yang juga telah diperhitungkan. Ketetapan tersebut kemudian diuji cobakan secara lansung. Hasil pengujian ini kemudian dievaluasi untuk mendapatkan kapasitas yang sesungguhnya. Dari iterasi ke-dua inilah akan diperoleh ketetapan kapasitas produksi yang sesungguhnya, sehingga dapat dilakukan perhitungan harga produksi dari komoditas tersebut, dari hasil penelitian hanya dapat ditentukan 2 komoditi yang layak untuk

Dengan karakteristik bahan baku yang bersifat benar-benar baru, maka penelitian tidak dapat dilakukan dengan menggunakan referensi yang ada, termasuk dengan adanya tuntutan harus ditemukannya alat produksi yang dapat menunjang efesiensi, sehingga pada penelitian ini, selain dihasilkannya produk yang memiliki kelayakan produksi, dihasilkan juga mesin produksi yang menunjang proses pembuatan produk yang sesuai dengan karakteristik bonggol jagung sebagai bahan baku.

Secara rinci hasil penelitian dapat diuraikan sebagai berikut:

\subsection{Tahap Evaluasi Produk Terdahulu}

Proses penelitian diawali dengan evaluasi terhadap kreasi yang telah dihasilkan pada penelitian sebelumnya, yaitu produk lighting bonggol jagung yang dibentuk melalui potongan melintang dari bonggol jagung yang ditempelkan satu persatu dengan mengikuti cetakan (mould) yang tersedia.

Pada tahun pertama penelitian telah ditetapkan 3 jenis modul yang akan digunakan, yaitu (1) Modul balok melintang, (2) Modul balok penampang, dan (3) Modul silinder.

Setiap modul bonggol jagung yang digunakan merupakan modul yang dihilangkan terlebih dahulu bagian luarnya.

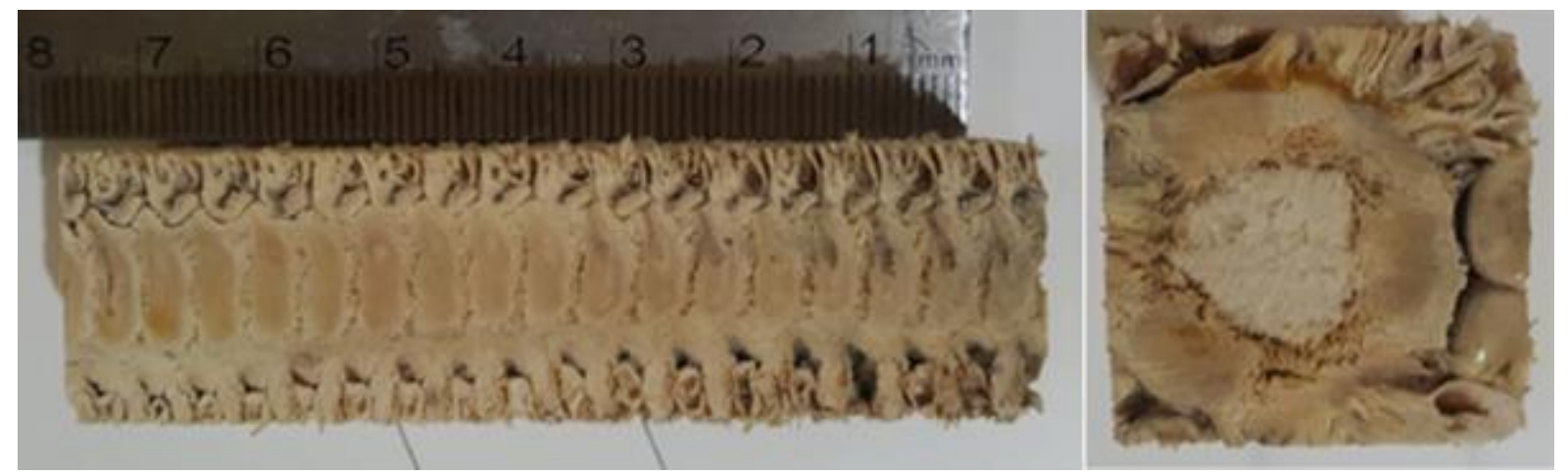

\section{Gambar 6. Penampang Jagung}

Produk hasil penelitian sebelumnya hanya menggunakan modul dalam bentuk selinder. Proses untuk mendapatkan modul tersebut membutuhkan alat agar lingkaran modul dapat dihasilkan secara cepat dan presisi. Akan tetapi, dengan karakteristik bonggol yang tidak dapat distandarisasikan (ukuran yang sangat beragam) menyebabkan proses ini tidak dapat memenuhi nilai efesiensi, selain menjadikan pembuatan modul sangat mengandalkan keterampilan tangan, hal ini juga menuntut kehati-hatian yang sangat tinggi, sehingga proses sangat membutuhkan waktu.

Ketika modul telah dibentuk, proses selanjutnya adalah merangkai modul tersebut pada mould yang sudah tersedia. Pada tahap ini, kebergantungan proses pada pekerjaan manual sangat mendominasi, selain bahwa setiap modul tidak memiliki standariasi ukuran, diperoleh bukti juga bahwa setiap modul yang dihasilkan belum

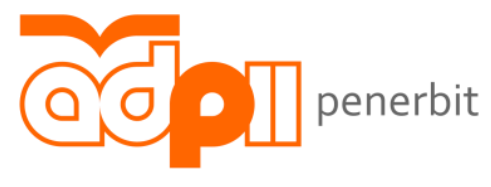

Penerbit Aliansi Desainer Produk Industri Indonesia 
tentu memiliki kualitas yang standar. Hal ini menyebabkan proses perangkaian modul membutuhkan waktu yang juga cukup tinggi dan kualitas perangkaian yang tidak dapat terjaga kualitasnya.

Setelah rangkaian modul dapat membentuk sesuatu (sesuai dengan mould yang tersedia) maka proses selanjutnya adalah proses pembentukan untuk mendapatkan permukaan yang rata. Proses ini juga sangat menuntut keterampilan manual dari pekerja untuk dapat menghasilkan kualitas permukaan yang optimal. Pada akhirnya, sejak pembuatan modul, proses perangkaian, hingga proses finishing produk, nilai kebergantungan terhadap keterampilan secara manual bersifat sangat tinggi, hal ini menyebabkan kualitas dari setiap pekerjaan tidak dapat distandarisasi, termasuk waktu pengerjaan dari sebuah produk.

Evaluasi dari desain produk sebelumnya juga mengindikasikan hal lain, yaitu aspek peluang pengembangan produk. Dengan proses yang ada, maka desain dari produk akan sangat bergantung pada desain mould yang tersedia, sementara pembuatan mould yang tersedia akan menuntut harga yang cukup tinggi, sementara fungsi atau komoditi yang tepat dengan karakteristik produksi yang ada akan sangat terbatas.

Berdasarkan beberapa hal tersebut diatas, maka untuk mendapatkan nilai efesiensi produksi dan kemungkinan pengembangan produk, penggunaan modul dalam bentuk penampang melintang untuk sementara harus ditinggalkan. Kebergantungan terhadap pekerjaan manual harus dapat ditekan sebesar mungkin agar dapat diperoleh ruang lingkup harga yang lebih fleksibel untuk mendapatkan harga yang realistis.

\subsection{Kajian Analisis terhadap kelayakan Mata Pisau Potong}

Salah satu faktor utama dari proses produksi bahan baku bonggol jagung adalah mata pisau yang tepat digunakan sesuai dengan karakteristik bonggol jagung. Pada penelitian sebelumnya, untuk mendapatkan potongan yang halus digunakan mata slitting dengan radius minimal 4 inch dari jenis non TCT. Untuk mendapatkan kualitas potongan yang baik, mata jenis ini cukup baik menghasilkan kualitas potongan yang diharapkan. Akan tetapi pada kuantitas produksi yang tinggi, mata gergaji jenis slitting memperlihatkan kendala yang cukup besar, yaitu tingkat kepresisian yang berubah akibat panas yang ditimbulkan dari pergesekan getah bonggol dengan bahan logam dari mata gergaji.

Besarnya putaran dari motor yang digunakan harus ditambah untuk dapat menghasilkan potongan yang halus, akan tetapi dengan putaran yang tinggi tersebut, maka panas yang dihasilkan menyebabkan pemuaian pada logam pembentuk gergaji, sehingga hasil potongan dari gergaji menjadi tidak presisi, sementara kepresisian menjadi satu faktor yang harus dipenuhi agar efesiensi proses perakitan modul dapat dicapai secara optimal.

Dimensi dari bonggol jagung yang tersedia menyebabkan radius dari mata gergaji harus besar. Pada penelitian yang dilakukan, disimpulkan bahwa diameter minimal yang harus dimiliki adalah 6 inch, hal ini diperlukan karena perlakuan yang diberikan tidak saja bersifat pemotongan, akan tetapi juga dalam bentuk pembelahan.

Dengan ukuran minimal 6 inch tersebut, maka pemuaian yang terjadi pada mata gergaji semakin cepat terjadi. Pada penelitan yang dilakukan, hanya dalam waktu 1 jam saja, gergaji sudah tidak dapat menghasilkan potongan yang presisi.

Eksperimen untuk mendapatkan solusi ini dicoba dengan memilih ketebalan mata gergaji yang cukup tebal. Pemilihan ketebalan gergaji hingga $2 \mathrm{~mm}$ cukup memberikan peluang yang lebih baik, akan tetapi pemuaian mata gergaji tetap terjadi, disamping bahwa tebal mata tersebut menjadikan harga mata menjadi lebih tinggi, sementara waktu pemuaian hanya bergeser sedikit (kurang lebih 2 jam). Ketebalan mata gergaji ternyata bukan faktor yang solutif terkait dengan dibutuhkannya potongan dalam kualitas yang tinggi.

Alternatif lain yang dicoba untuk memperoleh potongan yang presisi dan durabilitas yang tinggi dalam menghasilkan modul tersebut dicoba dengan memilih jenis mata gergaji, yaitu jenis TCT.

Pada eksperimen dari jenis TCT ini ternyata cukup solutif terhadap kebutuhan tidak terjadinya pemuaian, akan tetapi jenis TCT ini menghasilkan potongan yang tidak rapih. Alternatif untuk mengatasi permasalahan tersebut adalah dengan menambah daya dan perputaran dari motor yang dipilih. Untuk mengatasi keadaan tersebut, faktor yang ternyata penting adalah jumlah gigi yang harus dimiliki.

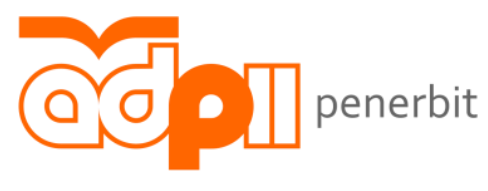

Penerbit Aliansi Desainer Produk Industri Indonesia 
Dari sekitan banyak mata gergaji yang telah dicoba, maka dapat disimpulkan bahwa kriteria yang harus dipenuhi oleh sebuah mata gergaji untuk bonggol jagung adalah (1) Tingkat kepresisian modul yang stabil, (2) Durabilitas bahan terhadap pemuaian, dan (3) Kualitas potongan yang tidak menyebabkan pecahan bonggol jagung.

Terhadap kriteria tersebut, maka diperoleh mata gergaji yang tepat untuk digunakan yaitu :

1. jenis mata gergaji TCT

2. diameter 7 inch dengan jumlah gigi 72

3. putaran mesin dari motor dengan jenis $1 \mathrm{KwH}$

4. Ketebalan mata gergaji minimal $1.2 \mathrm{~mm}$

5. Penetapan modul bonggol jagung

Kendala yang sangat besar pada modul yang dipilih dari penelitian sebelumnya, menyebabkan diperlukannya alternatif bentuk lain dari modul yang akan menjadi dasar bagi perancangan produk yang akan dikaji dengan mempertimbangkan :

a. Tingkat akurasi ukuran yang dapat dihasilkan oleh mesin secara kontinyu.

b. Waktu yang dibutuhkan untuk menghasilkan modul.

c. Keluasan terhadap peluang pengembangan produk

Dengan kriteria yang telah ditetapkan tersebut, diusulkan alternatif lain dari modul potongan penampang, yaitu modul kotak yang dihasilkan dari pembelahan dan pemotongan. Didasarkan pada ukuran bonggol jagung yang tersedia dari petani jagung, diperoleh ukuran kisaran bonggol jagung yaitu diameter $4 \mathrm{~cm}$ dan panjang paling besar $14 \mathrm{~cm}$. Dari ukuran tersebut, dapat diperoleh modul kotak dengan tiga jenis ukuran yaitu kotak dengan ketebalan $1.5 \mathrm{~cm}, 1.8 \mathrm{~cm}$, dan $2 \mathrm{~cm}$. Sedangkan panjang modul kotak yang dapat dihasilkan maksimal adalah $11 \mathrm{~cm}$. Mempertimbangkan kebutuhan modul yang seragam, diperoleh ukuran yang optimal adalah 7 $\mathrm{cm}$.

Beberapa hal yang menyebabkan ketetapan ini adalah keragaman ukuran yang dapat cenderung tersedia dari pasokan bahan baku bonggol dari petani pipil jagung. Terdapat kondisi unik dari ketersediaan bonggol jagung dari petani, pada masa musim kering jagung yang dihasilkan memiliki ukuran yang sangat kecil dan rapuh, sehingga tidak layak untuk dijadikan sebagai bahan baku. Pada musim hujan, sebagian jagung merupakan produksi masa kering, sehingga masih terdapat jagung-jagung yang berukuran kecil.

Sebagai catatan, jagung yang dapat digunakan pada penelitian ini adalah jagung dari jenis lokal, dan diperuntukan sebagai pipilan. Jagung manis dan jagung hibrida, walaupun memiliki ukuran yang besar, akan tetapi tidak memiliki kekuatan sebagai bahan baku, sifatnya sangat rapuh. Dengan modul yang berukuran $2 \mathrm{~cm}$ $\times 2 \mathrm{~cm} \times 7 \mathrm{~cm}$, diperoleh papan laminasi dengan ukuran lebar $38 \mathrm{~cm} \times 38 \mathrm{~cm}$ dengan ketebalan maksimal $2 \mathrm{~cm}$.

\subsection{Jenis Perekat}

Dengan mempertimbangkan keluasan dari peluang pengembangan produk yang dapat dirancang, maka diputuskan bahwa modul balok yang telah dihasilkan akan dirakit menjadi bahan baku dalam bentuk papan dan balok. Pada eksperimen yang dilakukan, luas papan yang memiliki kekuatan (struktur terhadap dirinya sendiri) adalah $38 \mathrm{~cm} \times 38 \mathrm{~cm}$.

Papan dibentuk dari susunan modul-modul balok bonggol jagung dengan susunan bata. Susunan ini dipilih untuk mendapatkan kekuatan konstruktif dari papan tersebut. Masing-masing modul balok disusun dengan direkatkan satu sama lain. Dari beberapa jenis perekat yang diujikan, diperoleh karakteristik yang paling baik untuk digunakan, yaitu lem jenis Lem kayu Aliphatic yang diformulasikan secara khusus untuk Finger Jointing, Laminating, dan Assembling.

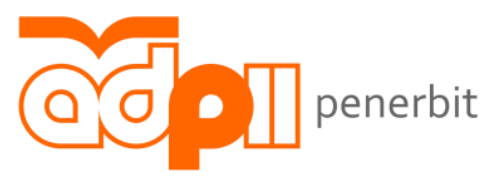

Penerbit Aliansi Desainer Produk Industri Indonesia 


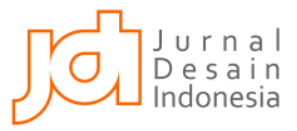

\subsection{Perancangan Mesin Produksi}

Jurnal Desain Indonesia Vol. 02 no. 02 - Aliansi Desainer Produk Industri Indonesia

Secara umum, peralatan yang digunakan untuk mengolah bonggol jagung adalah peralatan yang digunakan untuk kayu, akan tetapi, dengan karakteristik khas dari bonggol jagung, diperlukan perancangan mesin yang khusus.

Mesin produksi yang dirancang khusus untuk penelitian ini adalah:

1. Mesin pembentuk balok double blade.

2. Mesin potong balok.

3. Mesin hamplas drum.

4. Mesin hamplas sudut.

Mesin pembentuk balok double blade adalah mesin khusus yang dirancang untuk mendapatkan balok dengan kriteria yang telah disebutkan sebelumnya. Dengan telah ditetapkannya ukuran balok maksimal yang dapat dihasilkan, maka pada mesin balok yang dibuat, dibutuhkan 3 jenis pemisah yaitu jarak $1.5 \mathrm{~cm}, 1.8 \mathrm{~cm}$, dan 2 $\mathrm{cm}$.

Hasil eksperimen terhadap pembuatan mesin menunjukkan bahwa motor yang digunakan untuk menghasilkan kualitas yang optimal adalah sebagai berikut :
a. Jenis phase : Single phase electric motor
b. Tenaga : $1 \mathrm{HP} / 1 \mathrm{PK}(0,75 \mathrm{KW})$
c. Voltase : 220 Volt
d. Putaran : 1300-1500 RPM

Dengan spesifikasi motor dan mata gergaji yang telah ditetapkan, dapat diperoleh jumlah modul balok bonggol jagung sebanyak kurang lebih 1300 buah dalam sehari dengan tingkat kegagalan tidak melebihi 8\%.

Dengan pilihan motor dan mata pisau yang tepat tersebut, mesin dapat berjalan secara kontinyu selama 6 hari berturut-turut dengan kualitas balok yang dihasilkan yang sangat baik.

Pada penelitian, digunakan karyawan utama sebanyak 2 orang, dan mesin produksi yang dapat digunakan secara bergantian. Penambahan produksi tidak akan merubah kebutuhan dari mesin, dengan pertimbangan terdapat 3 tahap utama dari proses produksi.

Dengan pertimbangan kapasitas 2 orang karyawan utama, dan bantuan 4 orang karyawan pembantu, maka kapasitas produksi yang dapat dihasilkan adalah 180 buah produk, dengan kisaran harga Rp. 152.870, serta tingkat kegagalan hingga $8 \%$.

Dengan kapasitas tersebut, maka keuntungan perusahaan dapat diperoleh sebesar Rp. 10.181.167 setiap bulannya dengan asumsi penyewaan lahan sekitar Rp. 40.000.000, setiap tahunnya.

Perhitungan penyewaan lahan diasumsikan untuk penyewaan lahan di seputar kota Bandung, dengan kebutuhan ruang sebagai berikut:

1. Ruang Produksi in-door dengan luas $4 \times 6 \mathrm{~m} 2$

2. Ruang produksi out-door seluas $4 \times 6 \mathrm{~m} 2$

3. Ruang penyimpanan sekaligus pengeringan bonggol jagung seluas $3 \times 3 \mathrm{~m} 2$

4. Ruang perakitan dengan luas $4 \times 6 \mathrm{~m} 2$

5. Ruang display dan penyimpanan produk akhir $4 \times 6 \mathrm{~cm} 2$

Dengan pertimbangan tersebut, dibutuhkan setidaknya bangunan dengan luas minimal $96 \mathrm{~m} 2$, dan memiliki setidaknya pekarangan terbuka.

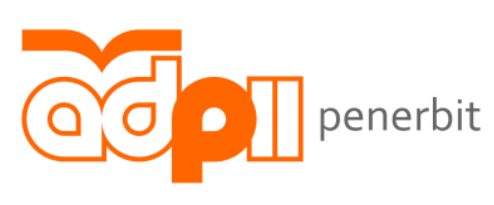

Penerbit Aliansi Desainer Produk Industri Indonesia 
Jurnal Desain Indonesia Vol. 02 no. 02 - Aliansi Desainer Produk Industri Indonesia

\begin{tabular}{|c|c|c|c|c|c|c|c|c|c|c|c|c|c|c|c|c|c|c|c|c|c|c|c|c|c|c|c|}
\hline & & & & \multicolumn{24}{|c|}{ tahun pertama } \\
\hline & & & & \multicolumn{2}{|r|}{1} & \multicolumn{2}{|r|}{2} & \multicolumn{2}{|r|}{\begin{tabular}{l|l}
3 & 1 \\
3
\end{tabular}} & \multicolumn{2}{|r|}{\begin{tabular}{l|l}
4 & -1
\end{tabular}} & \multicolumn{2}{|r|}{\begin{tabular}{l|l}
5 & 1 \\
\end{tabular}} & \multicolumn{2}{|r|}{6} & \multicolumn{2}{|c|}{7} & \multicolumn{2}{|r|}{8} & \multicolumn{2}{|r|}{9} & \multicolumn{2}{|c|}{10} & \multicolumn{2}{|r|}{11} & \multicolumn{2}{|r|}{12} \\
\hline gaj karyaman & 2,00 & $a b$ & 280 & & 5,60 & & 5.60 & & 5.80 & & 5,60 & & 5.80 & & 5,60 & & 5.60 & & 5.60 & & 5,60 & & 5,80 & & 5,60 & & 5.60 \\
\hline Biay latrik & 1,00 & bulan & 0.25 & & 0,25 & & 0.25 & & 0,25 & & 0,25 & & 0,25 & & 0,25 & & 0.25 & & 0,25 & & 0,25 & & 0,25 & & 0,25 & & 0.25 \\
\hline bahan baku bongeol & 1,0 & & 150 & & 1,50 & & 150 & & 1,50 & & 150 & & 150 & & 1,50 & & 150 & & 1,50 & & 1,50 & & 150 & & 1,50 & & 150 \\
\hline behan baku pernoriarg & $1, \infty$ & & 150 & & 1,50 & & 150 & & 1,50 & & 1,50 & & 1.50 & & 1,50 & & 150 & & 1,50 & & 1.50 & & 1,50 & & 1,50 & & 150 \\
\hline sewa bhan & 1,00 & bulan & 0.33 & & 0,33 & & 0.33 & & 0,33 & & 0,33 & & 0.33 & & 0,33 & & 0.33 & & 0,33 & & 0,33 & & 0.33 & & 0,33 & & 0.33 \\
\hline lain lain & $1, \infty$ & Bulan & 0.92 & & 0.92 & & 0.92 & & 0.92 & & 0.92 & & 0.92 & & 0.92 & & 0.92 & & 0,92 & & 0.92 & & 0.92 & & 0.58 & & 0.92 \\
\hline \multirow[t]{2}{*}{ impestaxi mesin } & 4,00 & jemis & 5,00 & & 20,00 & & & & & & & & & & & & & & & & & & & & & & \\
\hline & & & & & & & & & & & & & & & & & & & & & & & & & & & \\
\hline \multirow[t]{2}{*}{ serjualan produk } & & & 0,20 & a & $0, \infty$ & 0 & 0.00 & of & 0,00 & 40 & 8,00 & 120 & 24,00 & 120 & 24,00 & 120 & 24,00 & 120 & 24,00 & 120 & 24,00 & 120 & 24,00 & 120 & $24, \infty 0$ & 120 & 24,00 \\
\hline & & & & & & & & & & & & & & & & & & & & & & & & & & & \\
\hline pecgeluaran & & & & & $-30,10$ & & -20.10 & & $-10,10$ & & $-2,10$ & & 1390 & & 13,50 & & 1390 & & 13,90 & & $13 \times 9$ & & 1390 & & 13,50 & & 13.90 \\
\hline \multirow[t]{2}{*}{ keurtungan } & & & & & & & $-40,20$ & & $.50,29$ & & $-52,39$ & & $.38,49$ & & 24,59 & & $-10,69$ & & 3,22 & & 17,12 & & 31,02 & & 44,92 & & 58.82 \\
\hline & & & & & & & & & & & & & & & & & & & & & & & & & & & \\
\hline & & & & \multicolumn{24}{|c|}{ tahun bedsa } \\
\hline & & & & \multicolumn{2}{|r|}{1} & \multicolumn{2}{|r|}{2} & \multicolumn{2}{|r|}{3} & \multicolumn{2}{|r|}{4} & & 5 & & \begin{tabular}{|l|l|}
6 & 1 \\
\end{tabular} & & 7 & & 8 & & \begin{tabular}{l|l}
9 & \\
\end{tabular} & & 10 & & 11 & & 12 \\
\hline gaj karyaraan & $2, \infty 6$ & & 280 & & 5,60 & & 5.60 & & 5,60 & & 5,00 & & 5,60 & & 5,60 & & 5.60 & & 5,60 & & 5,60 & & 5.80 & & 5,60 & & 5,60 \\
\hline Baye listrik & 1,00 & bulan & 0.25 & & 0,25 & & 0,25 & & 0,25 & & 0,25 & & 0.25 & & 0,25 & & 0.25 & & 0,25 & & 0,25 & & 0,25 & & 0,25 & & 0.25 \\
\hline bohan taku bongeol & 1,00 & & 150 & & 1,50 & & 150 & & 1,50 & & 1,50 & & 150 & & 1,50 & & 150 & & 1.50 & & 150 & & 150 & & 1,50 & & 150 \\
\hline buhan baku pernuriang & $1, \infty$ & & 150 & & 1,50 & & 1,50 & & 1,50 & & 1,50 & & 150 & & 1,50 & & 150 & & 1,50 & & 1,50 & & 1,50 & & 1,50 & & 150 \\
\hline sewa bhan & 1,00 & bulan & 0.33 & & 0,33 & & 0.33 & & 0,33 & & 0,33 & & 0.33 & & 0,33 & & 0.33 & & 0,33 & & 0.33 & & 0.33 & & 0,33 & & 0.33 \\
\hline lain lain & $1, \infty$ & Bulan & 0.92 & & 0,92 & & 0.92 & & 0,92 & & 0.92 & & 0.92 & & 0,92 & & 0.92 & & 0,92 & & 0.92 & & 0,92 & & 0.92 & & 0.92 \\
\hline imeestasi mesin & 4,00 & jents & & & 0,00 & & & & & & & & & & & & & & & & & & & & & & \\
\hline & & & & & & & & & & & & & & & & & & & & & & & & & & & \\
\hline pertialan produk & & & 0,20 & 120 & 24,00 & 120 & 24,00 & 120 & 24,00 & 120 & 24,00 & 120 & 24,00 & 120 & 24,00 & 120 & 24,00 & 120 & 24,00 & 120 & 24,00 & 120 & 24,00 & 120 & 24,00 & 120 & 24,00 \\
\hline & & & & & & & & & & & & & & & & & & & & & & & & & & & \\
\hline pergetuaran & & & & & 13,50 & & 1390 & & 13,90 & & 13,90 & & 13.90 & & 13,50 & & 1390 & & 13,90 & & 13,90 & & 13.90 & & 13,50 & & 13.90 \\
\hline keurtungan & & & 58,82 & & 72,73 & & 27,80 & & 41,71 & & 55,61 & & 69,51 & & 83,41 & & 97,31 & & 111,22 & & 125,12 & & 139,02 & & 152,92 & & 166,82 \\
\hline
\end{tabular}

\section{Gambar 7. Kelayakan Industri}

Pada tabel diatas, dapat dilihat bahwa untuk pembuatan industri bonggol jagung, dengan asumsi tenaga kerja dan mesin yang paling minim, maka dibutuhkan modal sekitar Rp. 52.000.000, yang akan kembali pada akhir tahun pertama. sebagai catatan, hal ini dimungkinkan jika tidak terjadinya penjualan hanya berlangsung hingga bulan ke -4 , dengan asumsi bulan ke -5 terjadi penjualan dengan income $\mathrm{Rp} 8.000 .000,00$ atau setara dengan 40 buah item produk dengan harga minimal Rp 200.000, serta penjualan sebanyak 120 item di bulan ke- 6, maka kekuatan modal sebesar 52 jt tersebut dapat bertahan hingga bulan ke -8 , dan mulai bulan ke -9 grafik pendapatan akan terus naik dan mencapai break event point pada bulan ke -12 .

Industri ini, dapat dinilai layak mengingat bahwa keuntungan tahun kedua pada bulan ke -2 bisa mencapai Rp. 72.000.000, dan diakhir tahun kedua dapat mencapai Rp 166.000.000, dengan asumsi bahwa omset penjualan dapat secara kontinyu bertahan minimal pada nilai $\mathrm{Rp} 13.000 .000,00$.

Beberapa produk yang dihasilkan melalui penelitian ini dapat dilihat pada gambar berikut:

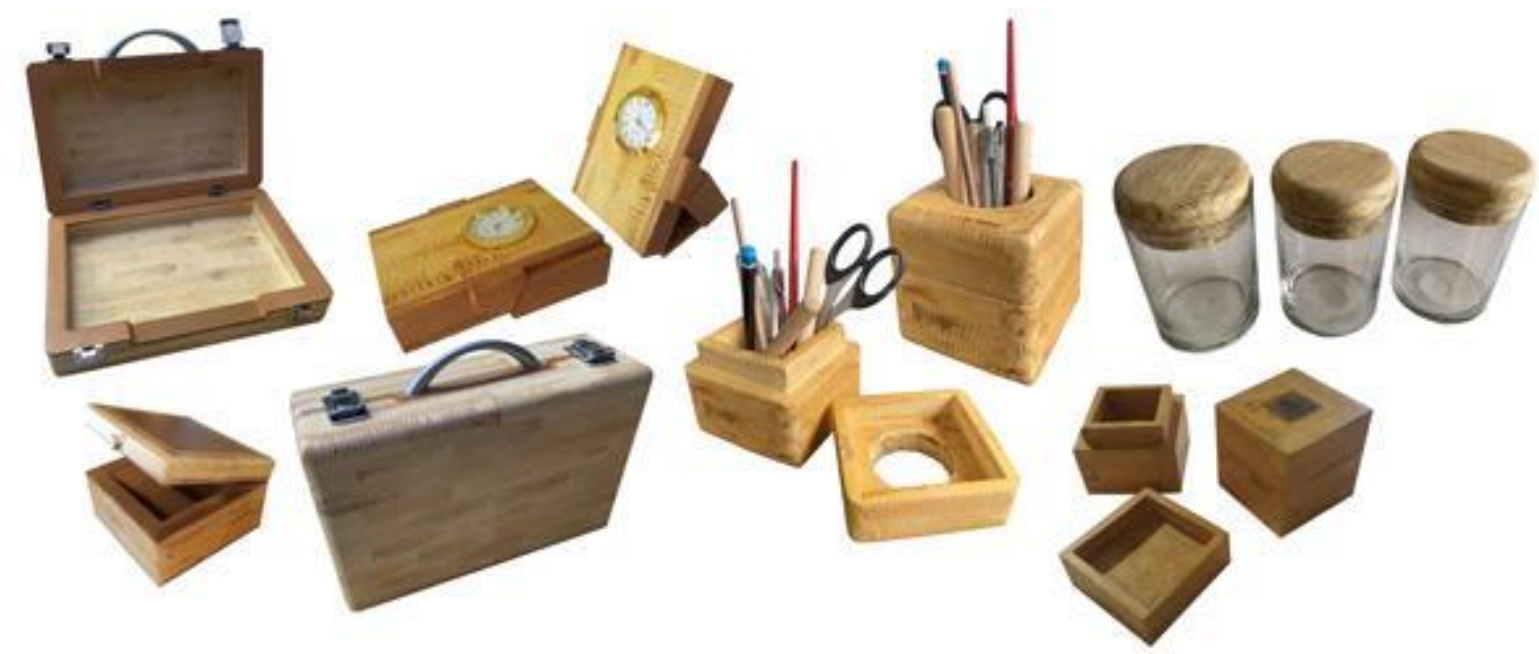

Gambar 8. Merchandise bonggol jagung

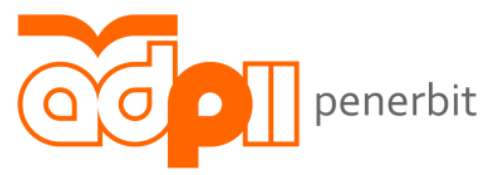

Penerbit Aliansi Desainer Produk Industri Indonesia 

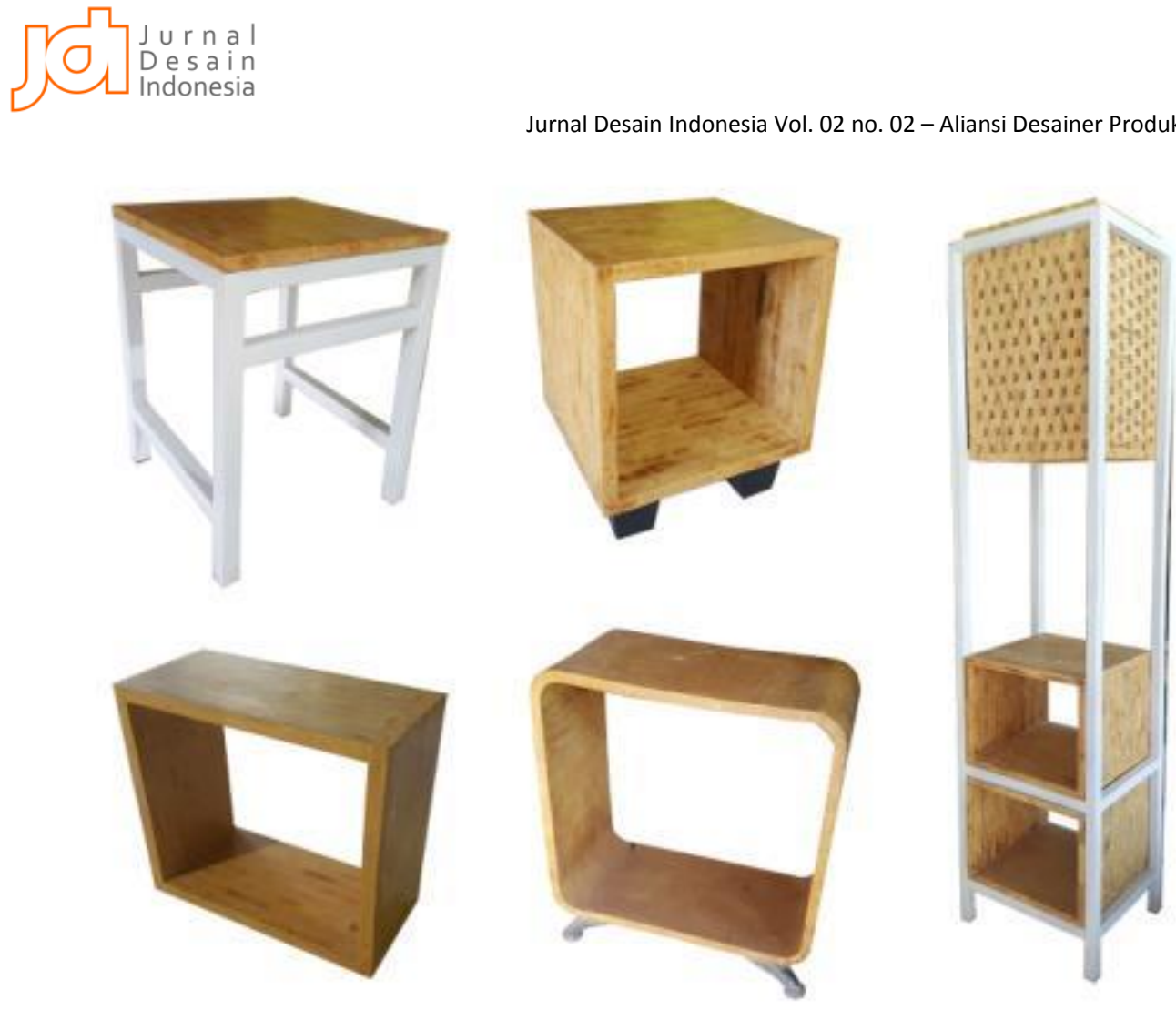

Page | 44

\section{Gambar 9. Furnintur berbasis papan laminasi}
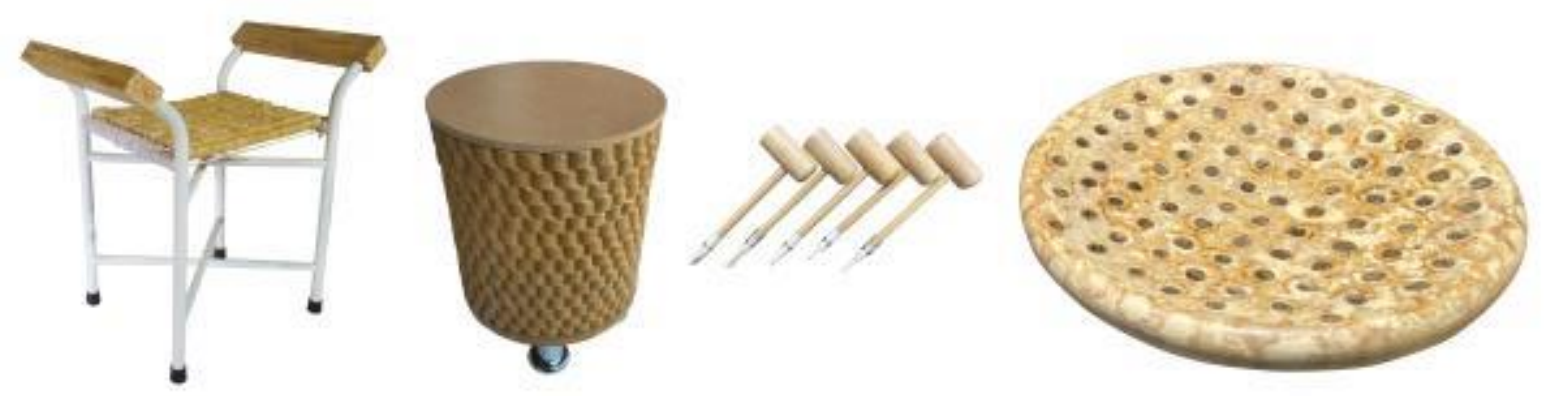

Gambar 10. Furniture dan Merchandise memanfaatkan penampang bongggol jagung

\section{Kesimpulan}

Berdasarkan tujuan dari penelitian ini, diperoleh kesimpulan bahwa bonggol jagung dapat dijadikan bahan baku yang layak bagi sebuah industri kreatif sub sektor craft, akan tetapi pembuktian secara real mengenai dapat berjalannya perekonomian industri perlu dikaji lebih lanjut.

Kendala utama yang dihadapi adalah terjadinya pandemi covid sejak bulan maret 2020, sehingga tidak semua proses dapat dilaksanakan, dan selama penelitian berlangsung dicoba untuk dilakukan proses yang ekivalen, seperti yang dapat diuraikan sebagai berikut

1. Proses optimalisasi dari sisi kualitas produk, sistem produksi, dan pembuatan komponen berjalan dengan sangat baik. Dari 24 komoditi yang dibuat, hanya terdapat 1 komoditi dari jenis rak, dikarenakan secara teknis memang tidak layak untuk diproduksi.

2. Proses untuk menghasilkan prototyping yang siap pasar terlaksana dengan baik.

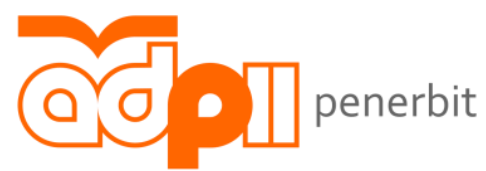

Penerbit Aliansi Desainer Produk Industri Indonesia 
3. Focus Group Discussion (FGD) terkait aspek desain industri tidak dapat dilaksanakan secara optimal, karena sejak bulan maret secara nasional telah memasuki masa pandemi. FGD dicoba digantikan dengan bentuk online, akan tetapi hasil sangat tidak memuaskan. Dengan memasuki era new normal pada bulan agustus, beberapa rekan dihadirkan untuk memberi masukan yaitu dari :

a. Beberapa rekan dari Asosiasi Desain Produk ditingkat nasional dan regional (ADPII).

b. Beberapa rekan dari Ikatan Seni Rupa dan Desain ITB

c. Beberapa rekan alumni dari FSRD ITENAS.

d. Kunjungan dari pasca sarjana FSRD Trisakti Jakarta.

e. Beberapa rekan dari lembaga swasta.

4. Proses Redesign dapat dilakukan dengan baik.

5. Proses Kajian terhadap strategi penetapan harga hanya dapat dilakukan secara teoritis, tidak dapat diuji-cobakan akibat dari kondisi perekonomian masyarakat yang menyebabkan sangat turunnya daya beli. Hampir semua segmentasi konsumen dari produk bonggol jagung yang telah ditetapkan sebelumnya tidak dapat diuji cobakan. Sejak pandemi berlangsung dari bulan maret 2020, Perbankan, Hotel, Café, dan lembaga lain tidak ada yang beroperasi, dan pada masa new normal hingga saat ini kondisi perekonomian belum pulih.

6. Proses pengajuan HaKI masih berlangsung, sejak bulan september 2020, 6 buah desain industri belum terbit hingga saat ini. Sementara itu, pangajuan hak cipta dari beberapa karya yang dihasilkan mengalami hambatan dan sedang dalam proses penyanggahan dikarenakan perbedaan tafsir terhadap pasal 43 c Undang Undang Hak Cipta no. 28 tahun 2014.

7. Proses uji produksi berlangsung dengan baik, hampir tanpa kendala.

8. Proses keikutsertaan pada pameran berskala nasional mengalami pembatalan dikarenakan masa pandemi, antara lain :

a. BRlliantpreneur 2020

b. Pameran Create, yang diselenggarakan oleh Dyandra pada tanggal 2 - 4 Oktober 2020 di JIEXPO Kemayoran.

c. Pameran Bandung Trade Expo Bandung 2020

9. Untuk mengantisipasi kegagalan ini, dalam upaya melihat respon masyarakat terhadap produk yang dihasilkan, 4 buah karya diajukan untuk mengikuti kompetisi Indonesian Good Design Selection yang diselenggarakan oleh Kementerian Republik Indonesia pada tahun ini, dan 4 karya tersebut dinyatakan lolos untuk masuk ke tahap penjurian akhir. Satu produk mendapatkan pernghargaan IGDS 2020.

10. Dengan ketidak ikut-sertaan tersebut, maka focus group discussion tahap 2 tidak dapat dilaksanakan, dan untuk mengantisipasi ini, digunakan media sosial online seperti facebook dan instagram, termasuk penggunaan marketplace seperti tokopedia.

\section{Referensi}

[1] J.-A. Johannessen, B. Olsen, and G. T. Lumpkin, "Innovation as newness: what is new, how new, and new to whom?," Eur. J. Innov. Manag., vol. 4, no. 1, p. 12, 2001.

[2] "Nurturing creative thinking - UNESCO Digital Library." https://unesdoc.unesco.org/ark:/48223/pf0000227680 (accessed Dec. 10, 2020).

[3] A. D’Angour, “THE DYNAMICS Of INNOVATION," Univ. Coll. Lond., p. 281, 1998.

[4] K. Talke, S. Salomo, J. E. Wieringa, and A. Lutz, "What about Design Newness? Investigating the Relevance of a Neglected Dimension of Product Innovativeness," J. Prod. Innov. Manag., vol. 26, no. 6, pp. 601-615, Nov. 2009, doi: 10.1111/j.1540-5885.2009.00686.x.

[5] A. Sachari and P. Widodo, "Visual Newness Value of Craft Products for Indonesian Public," Art Des. Stud., vol. 28, p. 10, 2015.

[6] W. D. Anjaningrum and A. P. Sidi, "Determinan Keunggulan Kompetitif dan Kinerja Industri Kreatif," J. Ekon. Mod., vol. 14, no. 1, pp. 40-56, Jul. 2018, doi: 10.21067/jem.v14i1.2379.

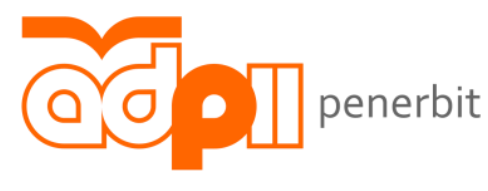

Penerbit Aliansi Desainer Produk Industri Indonesia 
[7] S. T. Bryant, K. Straker, and C. Wrigley, "Business model innovation by design: a review of design's role in business model innovation," Int. J. Des. Creat. Innov., vol. 8, no. 2, pp. 125-140, Apr. 2020, doi: 10.1080/21650349.2020.1717997.

[8] H. Vantrijp and E. Vankleef, "Newness, value and new product performance," Trends Food Sci. Technol., vol. 19, no. 11, pp. 562-573, Nov. 2008, doi: 10.1016/j.tifs.2008.03.004.

[9] Z. Ma, Z. Yang, and M. Mourali, "Consumer Adoption of New Products: Independent versus Page | 46 Interdependent Self-Perspectives," J. Mark., vol. 78, no. 2, pp. 101-117, Mar. 2014, doi: 10.1509/jm.12.0051.

[10] N. Crilly, J. Moultrie, and P. J. Clarkson, "Seeing things: consumer response to the visual domain in product design," Des. Stud., vol. 25, no. 6, pp. 547-577, Nov. 2004, doi: 10.1016/j.destud.2004.03.001.

[11] N. Crilly, J. Moultrie, and P. J. Clarkson, "Shaping things: intended consumer response and the other determinants of product form," Des. Stud., vol. 30, no. 3, pp. 224-254, May 2009, doi: 10.1016/j.destud.2008.08.001. 